\title{
Seasonal Variation in Polypeptide Profiles and Cellular Structure of Pecan Leaves
}

\author{
I.E. Yates, E.A. Carter, and T.A. Wilkins ${ }^{2}$ \\ Agricultural Research Service, U.S. Department of Agriculture, Russell Research Center, P. O. Box \\ 5677 Athens, GA 30613
}

\author{
B.W. Wood \\ Agricultural Research Service, U.S. Department of Agriculture, Southeastern Fruit and Tree Nut \\ Research Laboratory, P. O. Box 87, Byron, GA 31008
}

Additional index words. Carya illinoensis, ribulose 1,5-bisphosphate carboxylase, chlorophyll $a / b$ protein complex,

fruiting, chloroplast, electron microscopy

\begin{abstract}
Polypeptides from pecan [Carya illinoensis (Wangenh.) C. .Koch] leaves were separated by sodium dodecyl sulfate-polyacrylamide gel electrophoresis and visualized by silver staining. Pecan leaf protein profiles were similar irrespective of cultivar (Desirable and Stuart), leaflet position, reproductive status of the allied shoot, or seasonal leaf age relative to fruit development. The large subunit of ribulose 1,5-bisphosphate carboxylase and the majority of the other polypeptides were consistently present. However, the most striking change in the polypeptide composition was the seasonal decline of a polypeptide with an approximate molecular mass of $24.5 \mathrm{kDa}$. This leaf polypeptide was present in leaves collected in June and July, coinciding with the periods of initial fruit elongation and rapid increase in fruit volume. A detectable decrease occurred by mid-August, when kernel development was initiated. Changes in the abundance of this polypeptide relative to other polypeptides were observed over two growing seasons. Cells of young leaves collected early in the growing season contained more ribosomes and starch granules, but fewer vesicles and smaller electron-dense osmophilic granules than old leaves collected late in the growing season.
\end{abstract}

Many polycarpic tree crops are produced irregularly. This phenomenon is termed irregular bearing (Sparks, 1974) or alternate bearing (Monselise and Goldschmidt, 1982), and is a major problem in many "nut tree crops (Sparks, 1983). Good cultural practices can minimize alternate bearing on an orchard basis (Sparks, 1983). However, individual trees within the orchard still demonstrate irregular bearing patterns (Sparks, 1983). Overwhelming data indicate that return bloom in the spring is closely associated with maintaining healthy foliage during the previous growing season (Sparks and Brack, 1972; Worley, 1979a) to ensure adequate accumulation of carbohydrates in the shoots (Lockwood and Sparks, 1978a, 1978b; Worley, 1979b) and the roots (Lockwood and Sparks, 1978b; Smith and Waugh, 1938; Wood, 1989; Worley, 1979b) in pecan.

Physiological changes occurring in the pecan leaf during the growing season have been related to the stress of fruiting. Pecan leaves have been shown to be a source of photosynthate for the developing fruit from within 6 weeks of budbreak in mid-May until fruit maturity in mid-October (Davis and Sparks, 1974). In addition to the drain of assimilates from the leaf to support fruit development, the photosynthetic activity of pecan leaves decreases during late-season growth (Crews et al., 1980; Mielke, 1981; Wood, 1988). Leaves from shoots bearing fruit ("on") appear to maintain net photosynthetic rates that are at least $10 \%$ to $15 \%$ higher than those from shoots without fruit ("off") (Mielke, 1981; Wood, 1988). In addition, the total protein of late-season leaves is reduced compared to young early season

Received for publication 30 Jan. 1990. The technical expertise of Donnie Maxey in the preparation of photomicrographs is gratefully acknowledged. Trade names are used in this publication to provide specific information. Mention of a trade name does not constitute a guarantee or warranty of the product or an endorsement by the USDA over other products not mentioned. The cost of publishing this paper was defrayed in part by the payment of page charges. Under postal regulations, this paper therefore must be hereby marked advertisement solely to indicate this fact.

'Current address: Dept. of Agronomy, Texas Tech Univ., Lubbock, TX 79409. ${ }^{2}$ Current address: Dept. of Agronomy and Range Science, Univ. of California, Davis, CA 95616. leaves, with leaves from "off" shoots being $\approx 15 \%$ lower in protein than those from "on" shoots (Wood, 1988). "On" vs. "off" shoots and trees also differ in nutrient composition. During the "off" cycle, the leaves are lower in N, P, K, and Zn due to nutrient drain from the leaves by the developing fruit the previous season (Sparks, 1977). This reduction in nutrition has been proposed to be a factor in irregular bearing (Sparks, 1983). The objective of our study was to determine whether changes occur during the growing season in the relative abundance of polypeptides or in the cellular structure of pecan leaves.

\section{Materials and Methods}

Plant material. Leaves judged to be healthy by visible inspection were collected from 20-year-old 'Desirable' and 'Stuart' trees growing in a commercial orchard near Madison, Ga. Immediately after harvest, leaves were frozen in liquid $\mathrm{N}_{2}$, placed on dry ice, transported to the laboratory, and stored at - 80C until proteins were extracted.

During the 1985 growing season, leaves were collected only from 'Desirable'. Samples were taken randomly from fruiting and nonfruiting shoots of five trees. Leaflets were removed from three positions on each compound leaf: basal, middle, and terminal. Collections were made of young, early season leaves in June to coincide with the completion of leaf expansion and initial fruit growth (Davis and Sparks, 1974). Older leaves were collected later in the growing season (in September), after kernels had attained their maximum length (Davis and Sparks, 1974; Yates and Wood, 1989). No leaflets were sampled from the middle in the June collection from fruiting shoots. Leaflets were pooled for storage based on their position on the leaf and the fruiting status of the allied shoot. During the 1986 growing season, samples were taken monthly from June through October from 'Desirable' and 'Stuart' trees without regard to fruiting status of the allied shoot or leaflet position.

Protein extraction. A leaf sample of $0.5 \mathrm{~g}$ was cut into fine pieces $\approx 1$ to $2 \mathrm{~mm}^{2}$. The leaf pieces were pulverized to a fine powder in liquid $\mathrm{N}_{2}$ by use of a mortar and pestle. The powder 
was added to $1.5 \mathrm{ml}$ of extraction buffer in a Corex (Coming Glass Works, Corning, N.Y.) centrifuge tube on ice. To ensure that grinding in the mortar and pestle was adequate to completely macerate the leaf tissue, a companion sample for each monthly collection of 'Desirable' and 'Stuart' was treated as above and ground further with a Polytron microprobe homogenizer (Brinkman, Norwalk, Corm.) set at a speed of 2 for 5 sec. The extraction buffer contained $50 \mathrm{mM}$ Tris $\cdot \mathrm{HCl}, \mathrm{pH} 8.0$; $2 \% \mathrm{NaDodSO}_{4}$ (SDS); 5\% 2-mercaptoethanol; $1 \mathrm{mM}$ phenylmethylsulfonyl fluoride, $25 \mu \mathrm{g} \cdot \mathrm{ml}^{-1}$ leupeptin, and $0.12 \mathrm{~g}$ insoluble polyvinylpolypyrrolidone/g fresh weight. Samples were stirred vigorously for 10 to $20 \mathrm{sec}$, heated at $100 \mathrm{C}$ for, 3 rein, and centrifuged at $12,100 \times g$ for $20 \mathrm{~min}$ at $4 \mathrm{C}$. The supernatant was decanted, aliquoted, and frozen at $-80 \mathrm{C}$.

For protein concentration determinations, proteins were precipitated with $10 \%$, trichloroacetic acid and incubated at room temperature for $2 \mathrm{~min}$. Samples were applied to nitrocellulose membranes (Bio-Rad, Richmond, Calif.) and protein concentration determined by the method of Schaffner and Weissmann (1973) using bovine serum albumin (Sigma, St. Louis) as the standard.

Polyacrylamide gel electrophoresis (PAGE). Polypeptides were precipitated from the extracts. by the addition of 4 vol cold acetone and subsequent overnight incubation at $-20 \mathrm{C}$. The precipitates were recovered by centrifugation at $18,100 \times \mathrm{g}$ for 15 min at $4 \mathrm{C}$, solubilized in Laemmli buffer [0.0625 $\mathrm{M}$ Tris, $\mathrm{pH}$ 6.8, containing $10 \%$ glycerol (v/v), 5\% 2-mercaptoethanol $(\mathrm{v} / \mathrm{v}), 2.3 \%$ SDS (w/v)], and separated by SDS-PAGE (Laemmli, 1980) on $12.5 \%$ acrylamide gels. Each well was loaded with $10 \mu \mathrm{g}$ of total protein and electrophoretic separation of the polypeptides performed at $5 \mathrm{~mA} / \mathrm{gel}$ for $8 \mathrm{hr}$ at $5 \mathrm{C}$. Protein molecular mass standards (Sigma) were included as size markers and gels were silver-stained (Oakley et al., 1980).

Immunoblot analysis of pecan leaf polypeptides. Following electrophoresis, immunoblot analysis of the separated polypeptides was performed by methods originally developed by Towbin-et al. (1979) and with modifications similar to Cameron and Bassett (1988). The gel was sandwiched between two sheets of nitrocellulose (Bio-Rad) and immersed in transfer buffer containing $4 \%$ methanol, $0.624 \mathrm{mM}$ Tris, $4.8 \mathrm{mM}$ glycine, and $0.024 \%$ SDS. Transfer of the polypeptides from the gel to the surface of the nitrocellulose filter was achieved in an electroblot apparatus (Bio-Rad) at $60 \mathrm{~V}$ for $4 \mathrm{hr}$ at $4 \mathrm{C}$. Protein transfer was verified by staining the filter with Ponceau S (Sigma) or amido black and the gel with silver (Oakley et al., 1980). The large subunit (LS) of ribulose 1,5-bisphosphate carboxylase (Ru$\mathrm{BisCo}$ ) and light-harvesting chlorophyll $a / b$ protein complex of photosystem II (LHC-H) were detected on immunoblots after the filters were incubated with goat anti-rabbit alkaline phosphatase conjugate (Sigma) and stained with 5-bromo-4-chloro3-indolyl phosphate/p-nitro blue tetrazolium chloride. Polyclonal antibodies raised against RuBisCo LS isolated from $\mathrm{Eu}$ glena were provided by C. Bassett (Russell Research Center, USDA/ARS, Athens, Ga.). Polyclonal antibodies prepared against LHC-II extracted from pea leaves were provided by G. Schmidt (Univ. of Georgia, Athens). Monoclinal anitbodies raised against LHC-II from pea were provided by S. Darr (Indiana Univ., Bloomington) and designated Class IV-MLH9. These monoclinal antibodies were similar to the MLH5 antibodies described by Darr et al. (1986), except that MLH9 bind a low-molecularmass band of LHC-II $=20 \mathrm{kDa}$ (S. Darr, personal communication).

Microscopy. Leaves were collected in June and September for analysis of the cellular structure of early and late-season leaves, respectively. Leaf sections $\approx 0.5 \mathrm{~mm}^{2}$ were fixed overnight at $4 \mathrm{C}$ in $2 \%$ glutaraldehyde, and then for $1 \mathrm{hr}$ at $4 \mathrm{C}$ in $1 \%$ osmium tetraoxide in 0.085 M cacodylate buffer $(\mathrm{pH} 7.2)$, and dehydrated in an ethanol series. Following dehydration, leaf sections were infiltrated and embedded in resin (Spurr, 1969). Sections were stained with a mixture of $1 \%$ methylene blue and $1 \%$ azure II buffered with $1 \%$ sodium borate. Ultrathin sections were studied in a Joel Jem-100 CX II transmission electron microscope.

\section{Res u I t s}

Estimation of the relative seasonal levels of RuBisCo in 'Desirable' leaves. Polypeptide profiles were similar for basal, middle, and terminal leaflet positions of 'Desirable' leaves collected in June from both fruiting and nonfruiting shoots (Fig. 1). Likewise, all leaflets collected in September resulted in similar poly peptide profiles (Fig. 1). Positive identification of the band migrating with a molecular mass of $55 \mathrm{kDa}$ as RuBisCo LS was obtained by immunoblot analyses (Fig. 2). A band at $15 \mathrm{kDa}$ was presumed to be the small subunit (SS) of RuBisCo. Based on the relative intensity of silver staining of these bands, no significant differences were detectable in the level of the RuBisCo subunits relative to the majority of other polypeptides from pecan leaves, regardless of differences in leaf age, leaflet position on the leaf, or reproductive status of the allied shoot.

Decline of a leaf polypeptide as initial kernel development commences. Comparative analysis of polypeptides extracted from young, early season leaves collected in June and older, lateseason leaves collected in September revealed a distinctive dif-

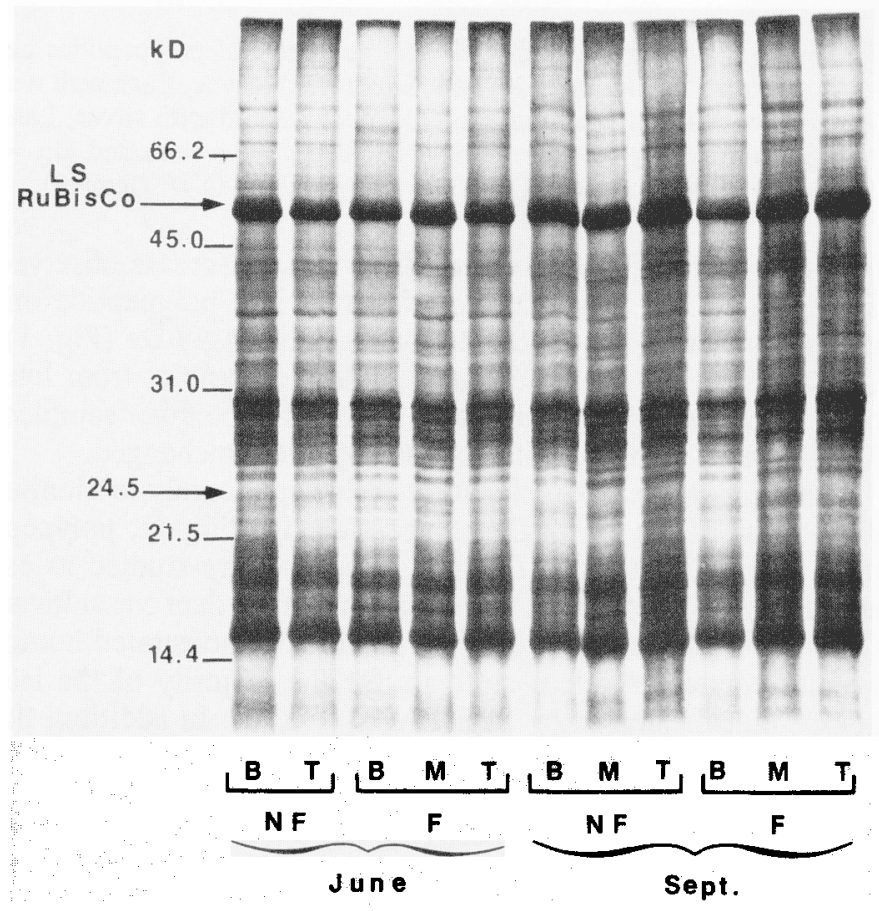

Fig. 1. SDS-polyacrylamide gel electrophoresis of polypeptides extracted from leaves of 'Desirable' pecan. Each well was loaded with $10 \mu \mathrm{g}$ total protein. Gels were stained with silver. The migration of molecular mass markers is indicated on the left. Lane designations at bottom of gel are leaflet position $(\mathrm{B}=$ basal, $\mathrm{M}=$ middle, $\mathrm{T}=$ terminal leaflet), reproductive status of the allied shoot $(\mathrm{NF}=$ nonfruiting, $\mathrm{F}$ = fruiting), and month of the leaf collection (June, September). 


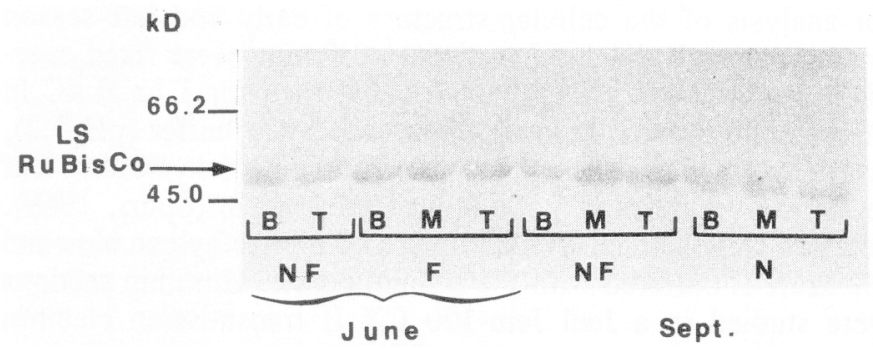

Fig. 2. Immunoblot analysis of pecan leaflet polypeptides shown in Fig. 1 probed with polyclonal antibodies raised against RuBisCo LS Lane designations same as Fig. 1
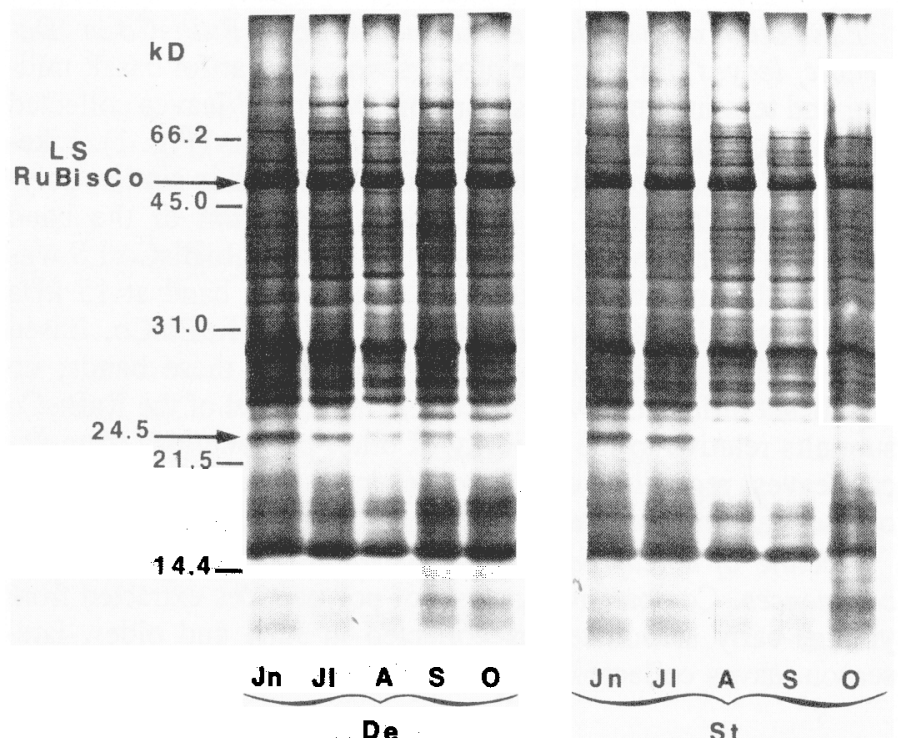

Fig. 3. SDS-polyacrylamide gel electrophoresis of polypeptides extracted from 'Desirable' (De) and 'Stuart' (St) leaves. Each well was loaded with $10 \mu \mathrm{g}$ total protein. Gels were stained with silver. Lane designations represent the month that leaves were collected $(\mathrm{Jn}=$ June, $\mathrm{J} 1=$ July, $\mathrm{A}=$ August, $\mathrm{S}=$ September, $\mathrm{O}=$ October $)$.

ference in polypeptide profiles. There was a decrease observed in September vs. June 'Desirable' leaves in a polypeptide migrating with an apparent molecular mass of $24.5 \mathrm{kDa}$ (Fig. 1). This polypeptide, while present in all leaflet samples from June collections, was absent, or nearly so, in all September samples. The intensity of other leaf proteins appeared unchanged.

During 1986, leaf samples were collected monthly to monitor the decline of the 24.5-kDa polypeptide. In addition, polypeptides from 'Stuart' and 'Desirable' leaves were studied to establish whether this protein was common to more than one cultivar. Qualitative evaluation of the polypeptides demonstrated homogeneity between the two cultivars for the majority of the leaf polypeptides analyzed by SDS-PAGE (Fig. 3). In addition, the polypeptide profiles of leaves were apparently identical regardless of extraction method. There were some slight differences in the polypeptide profiles between 'Desirable' leaves collected over the 2 years of this study (Figs. 1 and 3). However, it was not within the scope of the current study to characterize these differences.

The 24.5-kDa polypeptide identified in June samples of 'Desirable' during 1985 was abundant in leaves of 'Stuart' and 'Desirable' collected in June and July 1986 (Fig. 3). In both cultivars, the relative level of this polypeptide in pecan leaves began to decrease in August, and had diminished in leaves collected later in the season. LHC-II analysis indicated apparent molecular masses ranging from 23 to $35 \mathrm{kDa}$ (Darr et al., 1986). Because the decrease of the 24.5-kDa polypeptide in August leaf samples coincided with a previously reported decrease in the photosynthetic capacity of pecan leaves (Wood, 1988), we investigated whether this polypeptide was related to the LHC11.

In an attempt to correlate the 24.5-kDa polypeptide with LHCII, immunoblots containing total leaf proteins were challenged with polyclonal antibodies prepared against LHC-II. There were three polypeptides in pecan leaves that reacted strongly with polyclonal LHC-II antibodies (Fig. 4). Each reactive polypeptide had a molecular mass $>25 \mathrm{kDa}$, and was not reactive with the $24.5-\mathrm{kDa}$ polypeptide. Monoclinal antibody preparations specific for a low-molecular-weight LHC-II $(20 \mathrm{kDa})$ polypeptide in pea did not react with any polypeptides from pecan leaves (data not shown).

Cellular features of early vs. late-season pecan leaves. There were obvious seasonal differences in the cellular features of pecan leaves. Early season leaves (Fig. 5 A and B) had a moreuniform distribution of cytoplasmic contents and larger amounts of starch in their chloroplasts relative to late leaves. (Fig. $5 \mathrm{C}$ and D). Starch granules in palisade and spongy mesophyll cells of young, early season leaves (Fig. 5 A and B) constituted a large portion of the chloroplast. The chloroplasts of older, lateseason leaves appeared to be practically devoid of starch in both cell types (Fig. $5 \mathrm{C}$ and D). Even though the chloroplasts of late-season leaves are still well-defined as subcellular organelles (Fig. $5 \mathrm{C}$ and D), their internal structure was less compact than in early season leaves (Fig. 5 A and B). Electron-dense osmophilic granules apparent in early season leaves (Fig. 5A) were larger in late-season, older leaves (Fig. $5 \mathrm{C}$ and D). The cytoplasmic matrix of early season spongy mesophyll cells consisted of closely packed ribosomes with a few small vesicles (Fig. 5B). These vesicles-were located close to the outer chloroplast membrane toward the interior of the cell. The cells of lateseason leaves contained numerous, large vesicles located randomly throughout the cytoplasmic matrix (Fig. $5 \mathrm{C}$ and D).

\section{Discussion}

Degradation of RuBisCo during leaf senescence in herbaceous plants has been reported in several studies, but other proteins may also be proteolyzed during senescence (Leshem et al., 1986). Senescent wheat leaves had 50\% of the level of RuBisCo

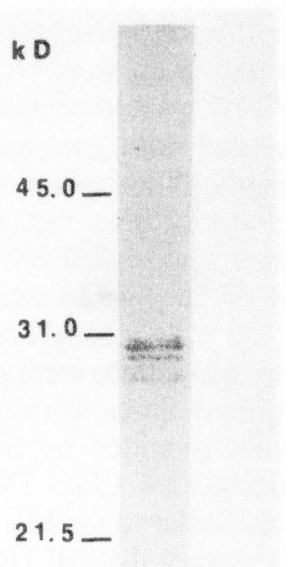

Fig. 4. Immunoblot analysis of proteins extracted from pecan leaves collected in June and probed with polyclonal antibodies prepared against LHC-II proteins. 

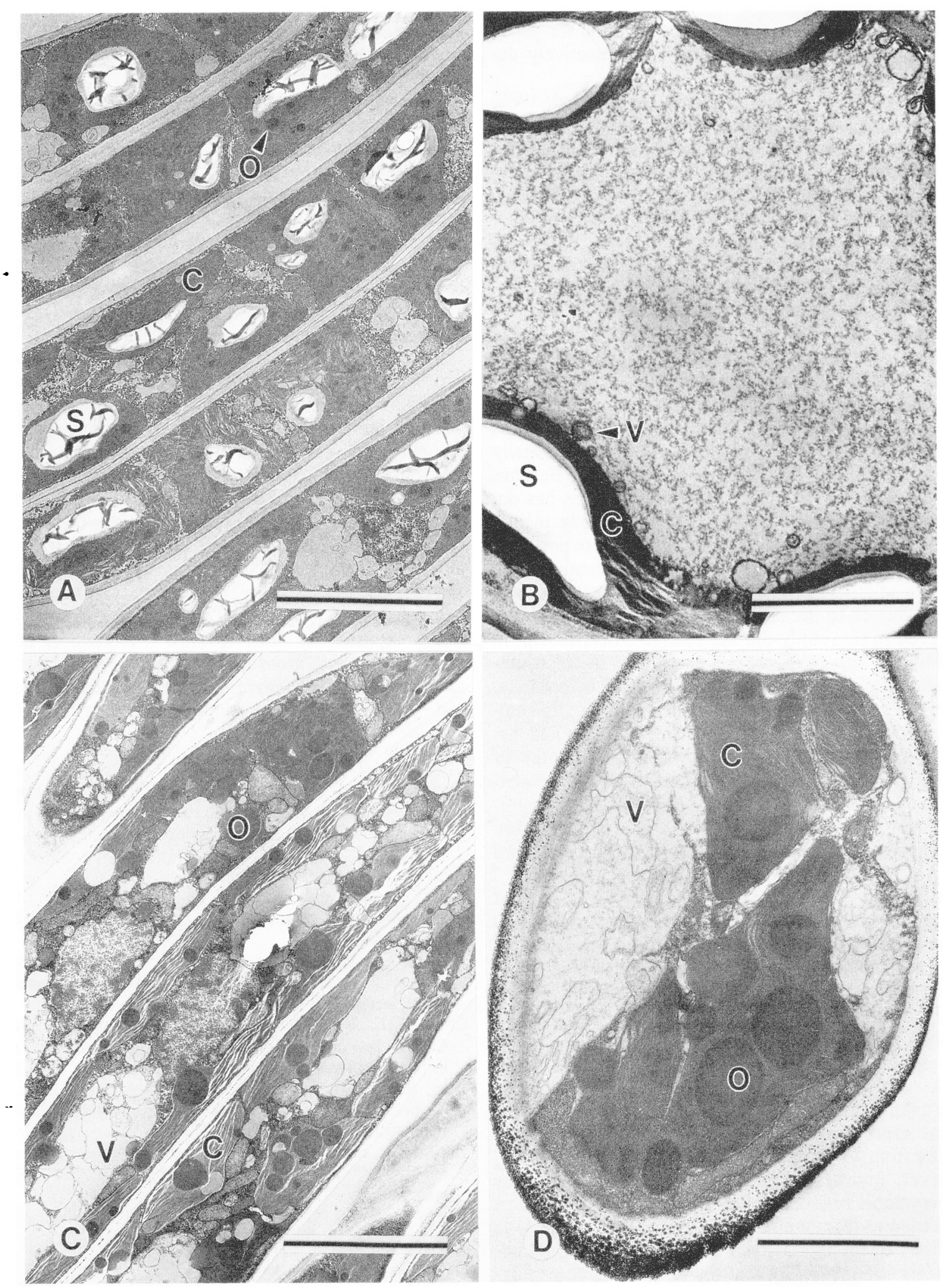

Fig. 5. Transmission electron micrographs of (A) early season palisade, (B) early season mesophyll, (C) late-season palisade, and (D) lateseason mesophyll cells of 'Desirable' leaves. $(\mathrm{c}=$ chloroplast, $\mathrm{o}=$ electron dense osmophilic granules, $\mathrm{s}=\mathrm{starch}$ granule, $\mathrm{v}=\mathrm{vesicle})$. Bar $=5 \mu \mathrm{m}(\mathbf{A}$ and $\mathbf{C})$ and $2 \mu \mathrm{m}(\mathbf{B}$ and $\mathbf{D})$.

present in young leaves (Wittenbach, 1979). Likewise, in senescent barley leaves, RuBisCo accounted for $85 \%$ of the soluble protein degraded (Friedrich and Huffaker, 1980). Friedrich and Huffaker (1980) and Racusen and Foote (1965) suggested that, in addition to $\mathrm{CO}_{2}$ fixation, RuBisCo may serve as a mobile $\mathrm{N}_{2}$ reserve within the plant. RuBisCo has been proposed to constitute a smaller proportion of the total soluble protein in senescent leaves than in young leaves because RuBisCo was 
selectively degraded (Brady, 1988). Our observation for pecan leaves is that RuBisCo does not appear to be selectively degraded in older leaves.

Both leaf photosynthetic activity (Mielke, 1981; Wood, 1988) and total leaf protein content (Wood, 1988) decreased. in lateseason pecan leaves compared to young, early season leaves. Resolution of pecan leaf polypeptides by one-dimensional SDSPAGE and immunoblot analysis was conducted to demonstrate whether a decrease in the level of RuBisCo LS relative to other polypeptides occurred during the same growth stage. Within the period examined in the current study and with the techniques used for analysis, there did not appear to be a preferential degradation of RuBisCo over other polypeptides. In the first season of this study, pecan leaves were collected in June shortly after shoot elongation was completed and again in September after photosynthetic capacity has been reported to be decreased (Wood, 1988). In the 2 nd year of the study, leaves were collected monthly from June to October. Analysis of the pecan leaf polypeptides suggested the level of RuBisCo must fluctuate proportionally with respect to the majority of the other polypeptides. Because the relative quantity of RuBisCo to other polypeptides has not been published for different leaf ages in other woody plants, analogies between pecan and other woody plants is not possible. Valid comparisons might be difficult even if information were available on the relative seasonal abundance of RuBisCo of a species closely related to pecan, such as hickory. Pecan leaves on the trees used in this study did not change color. Except in prolonged autumns, leaves of pecan trees grown in the southeastern United States seldom show evidence of fall colorations, as seen in most hickories. In contrast, fall colorations is common in the high-elevation pecan areas of New Mexico and Arizona. In the Southeast, during the low rainfall months of September and October, pecan leaves often yellow in nonirrigated orchards. However, this is due to lack of water, as evidenced by comparison of adjacent irrigated orchards or comparison of trees with and without functional emitters in the same orchard (D. Sparks, personal communication).

The one major exception to the consistency of the pecan leaf polypeptide profiles from young vs. old leaves was a band with molecular mass of $=24.5 \mathrm{kDa}$, a band that diminished relative to the other polypeptides by the onset of the period of initial kernel development. This polypeptide was present in all leaflets sampled in June for both cultivars (Desirable and Stuart), but was diminished in all September leaflets. Because of the reported decrease in photosynthetic activity of late-season pecan leaves (Mielke, 1981; Wood, 1988), an association of this polypeptide with chloroplasts was suspected. The LHC-II complex of chloroplast membranes have reported apparent molecular masses ranging from 23 to $35 \mathrm{kDa}$ (Darr et al., 1986; Thornber, 1975). However, immunoblot analysis of pecan leaf proteins with either polyclonal or monoclinal antibodies to LHC-II proteins of pea failed to react with the $24.5-\mathrm{kDa}$ peptide. Because of the specificity of the monoclinal antibodies, we cannot exclude completely the possibility that the $24.5-\mathrm{kDa}$ pecan polypeptide and $20-\mathrm{kDa}$ pea LHC-11 polypeptide are related. There was homology of pecan leaf polypeptides with molecular masses $>25 \mathrm{kDa}$ to the polyclonal antibodies prepared against LHC-II of peas, but not the $24.5-\mathrm{kDa}$ polypeptide. Knowing the identity of the $24.5-\mathrm{kDa}$ polypeptide would reveal whether this polypeptide is associated with chloroplasts in some manner, such as a structural component, or with other subcellular fractions.

Detailed studies have been made of the sequential steps in changes of the cellular structure during leaf aging in herbaceous plants [Phaseolus (Barton, 1966), spinach (Cran and Possingham, 1974)] and at least one woody plant [peach (Nii et al., 1988)]. The general anatomical features of cells from early vs. late-season pecan leaves shared several similarities with leaves of different ages from these other plant types. For example, older leaf cells in pecan as well as those of other plant types were more highly vacuolate, were depleted or nearly so of starch granules, and contained fewer ribosomes and larger electrondense osmophilic granules than young cells. The depletion of starch from the chloroplasts of late-season leaves may reflect the stress on the pecan leaf by kernel development (Davis and Sparks, 1974; Finch and Van Horn, 1936).

In summary, the relative quantity of RuBisCo to other polypeptides did not appear to be remarkably different in recently expanded, early vs. late-season pecan leaves. There was one consistent, reproducible difference in early vs. late-season pecan leaves: A $24.5-\mathrm{kDa}$ polypeptide was most prominent in June and July leaves, but began declining in August. The decline of this polypeptide is concurrent with several reported morphological and physiological events in the pecan tree. For example, this is the time that kernel development is initiated (Davis and Sparks, 1974) and leaf photosynthetic activity begins to decline (Wood, 1988). Changes in the cellular features of pecan leaves during aging were similar to those reported for both herbaceous and woody species; however, the chloroplasts of late-season pecan leaves did not exhibit the apparent loss of structural integrity reported for other species. It is possible that senescing pecan leaves with gross morphological evidence of aging, such as yellowing, would demonstrate selective degradation of RuBisCo and more severe degeneration of subcellular structures.

\section{Literature Cited}

Barton, R. 1966. Fine structure of mesophyll cells in senescing leaves of Phaseolus. Planta 71:314-325.

Brady, C.J. 1988. Nucleic acid and protein synthesis, p. 147-179. In: L.D. Nooden and A.C. Leopold (eds.). Senescence and aging in plants. Academic, New York.

Cameron, R.G. and C.L. Bassett. 1988. Inheritance of $\mathrm{C}_{4}$ enzymes associated with carbon fixation in Flaveria species. Plant Physiol. 88:532-536.

Cran, D.G. and J.V. Possingham. 1974. The effect of cell age on chloroplast structure and chlorophyll in cultured spinach leaf discs. Protoplasm 79:197-213.

Crews, C. E., R.E. Worley, J.P. Syvertsen, and M.G. Bausher. 1980. Carboxylase activity and seasonal changes in $\mathrm{CO}_{2}$ assimilation rates in three cultivars of pecan. J. Amer. Soc. Hort. Sci. 105: 798-801.

Darr, S. C., S.C. Somerville, and C.J. Arntzen. 1986. Monoclinal antibodies to the light-harvesting chlorophyll $a / b$ protein complex of photosystem II. J. Cell Biol. 103:733-740.

Davis, J.T. and D. Sparks. 1974. Assimilation and translocation patterns of carbon-14 in the shoot of fruiting pecan trees, Carya illinoensis Koch. J. Amer. Soc. Hort. Sci. 99:468-480.

Finch, A.H. and C.W. Van Horn. 1936. The physiology and control of pecan nut filling and maturity. Univ. of Ariz. Agr. Expt. Sta. Tech. Bul. 62.

Friedrich, J.W. and R.C. Huffaker. 1980. Photosynthesis, leaf resistances and ribulose-1,5-bisphosphate carboxylase degradation in senescing barley leaves. Plant Physiol. 65:1103-1107.

Laemmli, U.K. 1980. Cleavage of structural proteins during the assembly of the head of the bacteriophage T4. Nature (London) 227:680685.

Leshem, Y. Y., A.H. Halevy, and C. Frenkel. 1986. Processes and control of plant senescence. Elsevier, New York.

Lockwood, D.W. and D. Sparks. 1978a. Translocation of ${ }^{14} \mathrm{C}$ in 'Stuart' pecan in the spring following assimilation of ${ }^{14} \mathrm{CO}_{2}$ during the previous growing season. J. Amer. Soc. Hort. Sci. 103:38-45. 
Lockwood, D.W. and D. Sparks. 1978b. Translocation of ${ }^{14} \mathrm{C}$ from tops and roots of pecan in the spring following assimilation of ${ }^{14} \mathrm{CO}_{2}$ during the previous growing season. J. Amer. Soc. Hort. Sci. 103:4549.

Mielke, E.A. 1981. Effect of stress on pecan photosynthesis. Western Pecan Conf. Proc. 15:47-65.

Monselise, S.P. and E.E. Goldschmidt,. 1982. Alternate bearing in fruit trees, p. 128-173. In: J. Janick (cd.). Horticultural reviews. AVI, Westport, Corm.

Nii, N., S. Kawano, S. Nakamura, and T. Kuroiwa. 1988. Changes in the fine structure of chloroplast and chloroplast DNA of peach leaves during senescence. J. Jpn. Soc. Hort. Sci. 57:390-398.

Oakley, B. R., D.R. Kirsch, and, N.R. Morris. 1980. A simplified ultrasensitive silver stain for detecting proteins in polyacrylamide gels. Anal. Biochem. 105:361-363.

Racusen, D. and M. Foote. 1965. Protein synthesis in dark-grown bean leaves. Can. J. Bet. 43:817-824.

Schaffner, W. and C. Weissmann. 1973. A rapid, sensitive, and specific method for the determination of protein in dilute solution. Anal. Biochem. 56:502-514.

Smith, C.L. and J.G. Waugh. 1938. Seasonal variations in the carbohydrate and nitrogen content of roots of bearing pecan trees. $\mathrm{J}$. Agr. Res. 57:449460.

Sparks, D. 1974. The alternate fruit bearing problem in pecan. Annu. Rpt. Northern Nut Growers 65:145-158.

Sparks, D. 1977. Effects of fruiting on scorch, premature defoliation, and nutrient status of 'Chicksaw' pecan leaves. J. Amer. Soc. Hort. Sci. 102:669-673.
Sparks, D. 1983. Alternate fruit bearing in nut trees. Annu. Rpt. Northern Nut Growers 74:197-230.

Sparks, D. and C.E. Brack. 1972. Return bloom and fruit set of pecan from leaf and fruit removal. HortScience 7:131-132.

Spurr, A.R. 1969. A low-viscosity epoxy resin embedding medium for electron microscopy. J. Ultrastruct. Res. 26:31-43.

Thornber, J.P. 1975. Chlorophyll-proteins: Light-harvesting and reaction center components of plants. Annu. Rev. Plant Physiol. 26:127158.

Towbin, H., T. Staehelin, and J. Gordon. 1979. Electrophoretic transfer of proteins from polyacrylamide gels to nitrocellulose sheets: Procedure and some applications. Proc. Natl. Acad. Sci. USA $76: 4350-4354$.

Wittenbach, V.A. 1979. Ribulose bisphosphate carboxylase and proteolytic activity in wheat leaves from anthesis through senescence. Plant Physiol. 64:884-887.

Wood, B.W. 1988. Fruiting affects photosynthesis and senescence of pecan leaves. J. Amer. Soc. Hort. Sci. 113:432-436.

Wood, B.W. 1989. Pecan production responds to root carbohydrates and rootstock. J. Amer. Soc. Hort. Sci. 114:223-228.

Worley, R.E. 1979a. Pecan yield, quality, nutlet set, and spring growth as a response of time of fall defoliation. J. Amer. Soc. Hort. Sci. 104:192-194

Worley, R.E. 1979b. Fall defoliation date and seasonal carbohydrate concentration of pecan wood tissue. J. Amer. Soc. Hort. Sci. 104:195199.

Yates, I.E. and B.W. Wood. 1989. Organogenesis from immature pecan embryonic axes in vitro. J. Amer. Soc. Hort. Sci. 114:10251029. 